\title{
Salidroside overcomes dexamethasone resistance in T-acute lymphoblastic leukemia cells
}

\author{
YA-NA NIU, YAN ZENG, FANG-FANG ZHONG, SI-LI LONG, DAN-WEI REN, XIANG QIN and WEN-JUN LIU \\ Department of Pediatric Hematology, The Affiliated Hospital of Southwest Medical University and \\ Birth Defects Clinical Medical Research Center of Sichuan Province, Luzhou, Sichuan 646000, P.R. China
}

Received April 10, 2020; Accepted March 19, 2021

DOI: $10.3892 /$ etm.2021.10068

\begin{abstract}
The aim of the present study was to analyze whether the use of salidroside (SAL) could overcome dexamethasone (DEX) resistance in T-acute lymphocytic leukemia cells. The human T-ALL DEX-resistant cell line, CEM-C1 and the DEX-sensitive cell line, CEM-C7 were used in the current study. The proliferation inhibition rates in these cells, treated with SAL and DEX alone, and in combination were detected using a Cell Counting Kit- 8 assay, while the morphological changes of the cells were observed using an inverted microscope. Reverse transcription-quantitative PCR was used to detect the mRNA expression levels of the c-Myc and LC3 genes, while flow cytometry was used to detect the cell cycle distribution and the rate of apoptosis. In addition, western blot analysis was used to detect the protein expression levels of c-Myc, BCL-2, Bax, cleaved PARP and LC3. and acridine orange staining was used to detect the changes in acidic autophagy vesicles. It was found that SAL could effectively inhibit cell proliferation and induce apoptosis in the CEM-C1 and CEM-C7 cells. In addition, SAL promoted the induction of autophagy. The protein expression levels of c-Myc in the CEM-C1 cells were significantly higher compared with that in the CEM-C7 cells. SAL downregulated the mRNA expression levels of the c-Myc gene and protein in a dose-dependent manner. This suggested that SAL could inhibit the proliferation of the CEM-C1 and CEM-C7 cells, induce apoptosis and autophagy and overcome DEX resistance in the CEM-C1 cells. The mechanism may be associated with the downregulation of c-Myc.
\end{abstract}

Correspondence to: Professor Wen-Jun Liu, Department of Pediatric Hematology, The Affiliated Hospital of Southwest Medical University and Birth Defects Clinical Medical Research Center of Sichuan Province, 25 Taiping Street Luzhou, Sichuan 646000, P.R. China

E-mail: liuwenjun_1@163.com

Key words: salidroside, acute lymphoblastic leukemia, dexamethasone, drug resistance

\section{Introduction}

T-cell acute lymphoblastic leukemia (T-ALL) is an aggressive malignant tumor, that originates from T-cell precursors and has a high degree of genetic, immune phenotypic and clinical heterogeneity $(1,2)$. It accounts for $\sim 15 \%$ childhood ALL and $25 \%$ adult ALL worldwide (3). Administration of glucocorticoids (GC) is an important part of T-ALL treatment. GCs enter the cell by passive diffusion, where they bind to the GC receptor (GR; encoded by the $\mathrm{NR} 3 \mathrm{C} 1$ gene), which is a member of the nuclear receptor family of ligand-dependent transcription factors (4-6). The activated receptor is then translocated to the nucleus, where it activates target genes, including NR3C1 itself, BCL-2, glucocorticoid-induced leucine zipper, Kruppel-like factor-13, NFKB inhibitor a and period 1, with assistance from chaperone and transporter proteins, and binds to GR elements (GREs) (7). GR-induced activation or repression of gene transcription controls apoptosis of normal and malignant lymphocytes (8). In lymphoid cells, GR induces the mRNA expression level of BCL2L11, which encodes the proapoptotic BH3-only factor, BIM, triggering apoptosis (9). In dexamethasone (DEX)-resistant ALL, the activated GR cannot bind to the BIM intronic region to trigger apoptosis (10). Therefore, resistance to GC is one of the most common causes of T-ALL treatment failure or relapse (11).

Salidroside (SAL) is the main active ingredient of Rhodiola. It is the glycoside of a phenolic compound. Several studies have shown that SAL has a potential anti-cancer effect (12-17). Therefore, SAL has become potential drug candidate for cancer treatment. Recently, another study has shown that SAL could improve the microenvironment of hypoxic tumors and reverse the resistance to platinum drugs in hepatocellular carcinoma (18). Thus, the human T-ALL GC DEX-resistant cell line, CEM-C1 and the DEX-sensitive cell line, CEM-C7 were selected as cell lines to investigate reversal of tumor resistance caused by SAL.

The proto-oncogene, c-Myc is a transcription factor, which belongs to the helix-loop helix-leucine zipper protein family, and functions primarily to maintain cell proliferation, differentiation, apoptosis and normal cell cycle (19). It has been found that c-Myc was associated with acute myeloid leukemia drug resistance (20). Mounting evidence also suggests that downregulation of c-Myc mRNA expression may increase the sensitivity of tumor cells to chemotherapeutic agents, 
including enhancing the sensitivity of breast cancer cells to palbociclib (21), the sensitivity of human glioblastoma cells to temozolomide (22), and the sensitivity of malignant mesothelioma cells to the p21-activated kinase blockage-induced cytotoxicity (23). In the present study, it was found that CEM-C1 cells exhibited higher protein expression levels of c-Myc compared with those in CEM-C7 cells. Since c-Myc has been associated with drug resistance in various studies (24-27), the present study aimed to reveal the anti-leukemic effect and reversal resistance effect of SAL, and to investigate c-Myc in T-ALL cells and its association with DEX resistance.

\section{Materials and methods}

Reagents. SAL (purity, >99\%) was purchased from Chengdu Ruifensi Biotechnology Co., Ltd. RPMI 1640 culture medium was purchased from HyClone (GE Healthcare Life Sciences), while fetal bovine serum was purchased from Zhejiang Tianhang Biotechnology Co., Ltd., and penicillin-streptomycin was purchased from Beyotime Institute of Biotechnology. Cell Counting Kit (CCK)-8 assay kit was purchased from Dojindo Molecular Technologies Inc., while DEX (Chinese medicine standard, H41020036) was purchased from Shanghai Shyndec Pharmaceutical Co., Ltd., and the cell cycle detection kit was purchased from Nanjing KeyGen Biotech Co., Ltd., and the Annexin V-FITC/PI apoptosis kit was purchased from BD Biosciences. The total RNA extraction kit was purchased from Tiangen Biotech Co., Ltd., while the reverse transcription and quantitative PCR (qPCR) kits were purchased from Toyobo Life Science, and the acridine orange stain was purchased from Biotopped Life Sciences. The rabbit anti-human c-Myc and GAPDH antibodies were purchased from ProteinTech Group, Inc., while the rabbit anti-human LC3A/B, Bax, BCL-2 and cleaved PARP antibodies were purchased from Cell Signaling Technology, Inc., and the goat anti-rabbit IgG-HRP antibody was purchased from BIOSS. Lastly, the PCR primers were synthesized by Shanghai Shenggong Biology Engineering Technology Service, Ltd.

Cell lines and culture. The CEM-C1 and CEM-C7 cell lines were donated by Professor Ma Zhigui (Department of Pediatric Hematology and Oncology, West China Second Hospital of Sichuan University, Chengdu, China) and were cultured in RPMI 1640 medium supplemented with $10 \%$ fetal bovine serum and $100 \mu \mathrm{g} / \mathrm{ml}$ streptomycin and $100 \mathrm{U} / \mathrm{ml}$ penicillin at $37^{\circ} \mathrm{C}$ in a humidified incubator with $5 \% \mathrm{CO}_{2}$. The medium was changed every 2 to 3 days and the cells were passaged once before the start of the experiments.

Drug dissolution. SAL (1 g) was dissolved in sterile PBS $(3 \mathrm{ml})$, made into a liquid and frozen in aliquots at $-20^{\circ} \mathrm{C}$. The compound was diluted in RPMI 1640 medium to the required concentration prior to the experiment.

CCK8 assay. The CEM-C7 and CEM-C1 cells were used in the logarithmic growth phase and plated in 96-well microplates $\left(1.5 \times 10^{5}\right.$ cells/well), then different concentrations of SAL (5.0, $7.5,10.0,12.5$ and $15.0 \mathrm{mg} / \mathrm{ml})$ were added. At the same time, the blank group (containing only culture medium and no cells) and the control group (containing only cells and culture
Table I. Sequences of the primers for quantitative PCR.

\begin{tabular}{lc}
\hline Primer name & \multicolumn{1}{c}{ Primer sequence } \\
\hline c-Myc & F: 5'-CTACCCTCTCAACGACAGCA-3' \\
& R: 5'-AGAGCAGAGAATCCGAGGAC-3' \\
LC3 & F: 5'-CAGCGTCTCCACACCAATCT-3' \\
& R: 5'-TCTCCTGGGAGGCATAGACC-3' \\
GAPDH & F: 5'-CAATGACCCCTTCATTGACC-3' \\
& R: 5'-GACAAGCTTCCCGTTCTCAG-3'
\end{tabular}

F, forward; R, reverse.

medium) were prepared. A total of 4 replicate wells were used for each group. Following incubation for 20, 44 and 68 h, $10 \mu \mathrm{l}$ CCK8 solution was added to each well, then the cells were incubated for another $4 \mathrm{~h}$, after which time the optical density (OD) was measured using a microplate reader at $450 \mathrm{~nm}$. The experiment was repeated 3 times. The percentage cell inhibition rate (\%) was calculated using the following formula: Cell inhibition $=(O D$ value of control group-OD value of experimental group)/(OD value of control group-OD value of blank group) $\mathrm{x} 100 \%$.

The CEM-C7 and CEM-C1 cells were used in the logarithmic growth phase and plated in 96-well microplates $\left(1.5 \times 10^{5}\right.$ cells/well), then they were treated with different concentrations of DEX. The CEM-C7 cells were treated with $0.25,0.5,1.0,1.5$ and $2.0 \mu \mathrm{g} / \mathrm{ml} \mathrm{DEX}$ with or without $1.5 \mathrm{mg} / \mathrm{ml} \mathrm{SAL} \mathrm{(cell} \mathrm{inhibition} \mathrm{rate}<4 \%$ ), while the CEM-C1 cells were treated with 25, 50, 100, 150 and $200 \mu \mathrm{g} / \mathrm{ml} \mathrm{DEX}$ with or without $1.5 \mathrm{mg} / \mathrm{ml} \mathrm{SAL} \mathrm{(cell} \mathrm{inhibition} \mathrm{rate}<4 \%$ ). Following incubation for $44 \mathrm{~h}, 10 \mu \mathrm{l} \mathrm{CCK} 8$ solution was added to each well, then the cells were incubated for another $4 \mathrm{~h}$, after which time the OD was measured using a microplate reader at $450 \mathrm{~nm}$. The experiment was repeated 3 times. The half inhibitory concentration $\mathrm{IC}_{50}$ was calculated using the GraphPad Prism v8.0.2 software (GraphPad Software, Inc.). The resistance index (RI) was calculated using the following equation: $\mathrm{RI}=\mathrm{IC}_{50}$ of resistant cells $/ \mathrm{IC}_{50}$ of sensitive cells. The reversal fold (RF) was calculated as follows: $\mathrm{RF}=\mathrm{IC}_{50}$ of resistant cells $/ \mathrm{IC}_{50}$ following addition of the reversal agent.

Observation of cell morphology. The CEM-C1 and CEM-C7 cells, in the logarithmic growth phase, were treated with $1.5 \mu \mathrm{g} / \mathrm{ml} \mathrm{DEX}$ for $48 \mathrm{~h}$, then the morphological changes in the cells were observed under a light microscope and images were captured (magnification, x400).

Reverse transcription-qPCR (RT-qPCR) analysis. The CEM-C1 and CEM-C7 cells, in the logarithmic growth phase, were seeded in a 6 -well culture plate $\left(5 \times 10^{6}\right.$ cells/well $)$. The following experimental groups were used: Control group (0 $\mathrm{mg} / \mathrm{ml} \mathrm{SAL})$ and the experimental groups (5.0, 7.5 and $10.0 \mathrm{mg} / \mathrm{ml} \mathrm{SAL})$. The cells were cultured for $48 \mathrm{~h}$, then RNA was extracted using TRIzol ${ }^{\circledR}$, according to the manufacturer's instructions (Invitrogen; Thermo Fisher Scientific, Inc.). cDNA was generated using RT and the TOYOBO reverse transcriptase kit. The mRNA expression levels of c-Myc 
A

CEM-C1

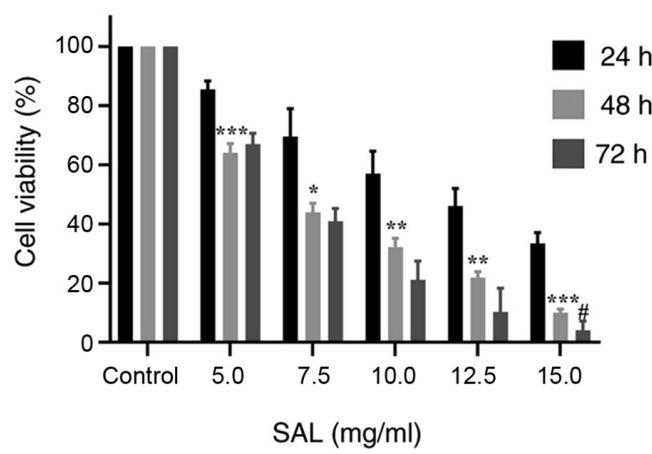

B

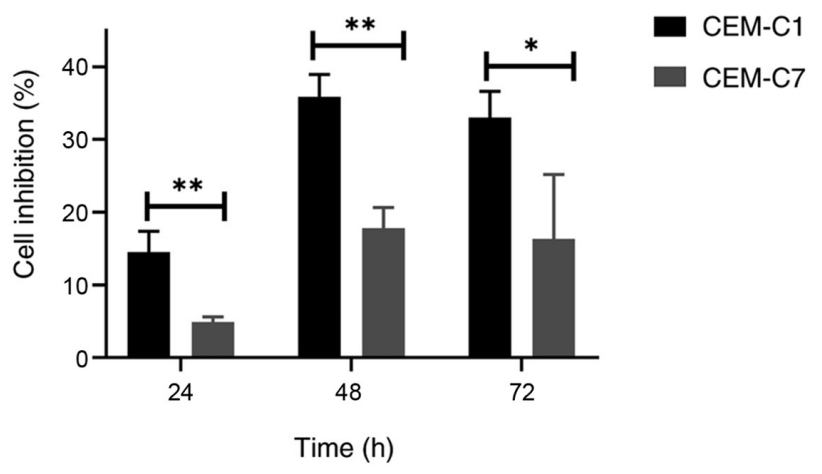

CEM-C7

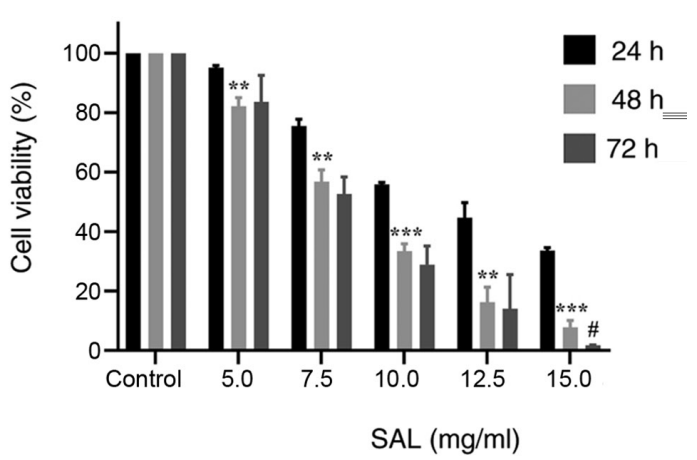

Figure 1. Effects of different concentrations of SAL and at different time periods on the CEM-C1 and CEM-C7 cells. (A) The CEM-C1 and CEM-C7 cells were treated with different concentrations of SAL for 24,48 and $72 \mathrm{~h}$, then cell viability was measured. ${ }^{*} \mathrm{P}<0.05,{ }^{* * *} \mathrm{P}<0.01,{ }^{* * * *} \mathrm{P}<0.001$ vs. $24 \mathrm{~h}$. ${ }^{\#} \mathrm{P}<0.05 \mathrm{vs} .48 \mathrm{~h}$. (B) The CEM-C1 and CEM-C7 cells were treated with $5.0 \mathrm{mg} / \mathrm{ml} \mathrm{SAL}$ for the indicated time periods and subsequently incubated with Cell Counting Kit-8 solution. The data are presented as the mean $\pm \mathrm{SD} .{ }^{*} \mathrm{P}<0.05,{ }^{* *} \mathrm{P}<0.01$. SAL, salidroside.

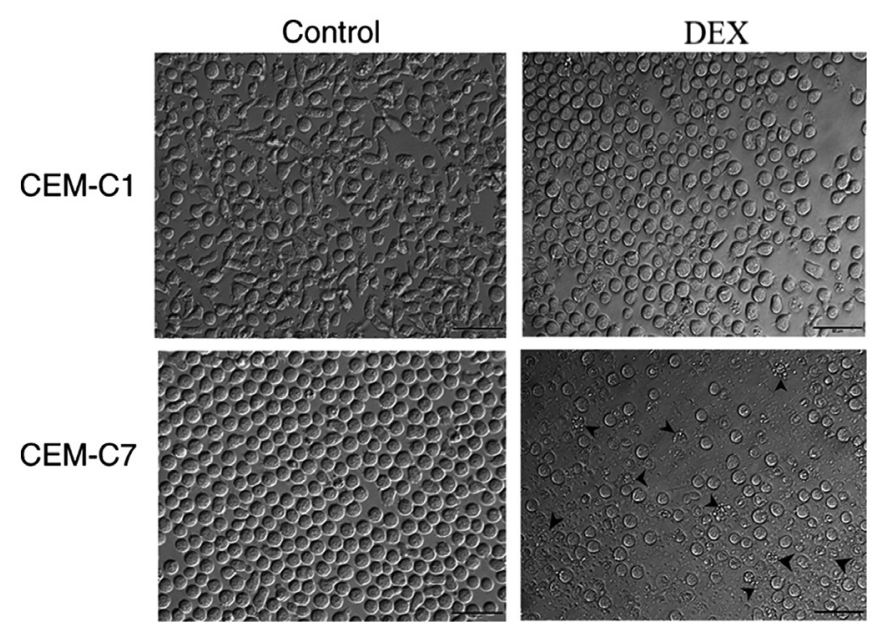

Figure 2. Cell morphology was observed using a light microscope. The changes in cell morphology were monitored following treatment of the DEX-resistant, CEM-C1 and DEX-sensitive, CEM-C7 cell lines with $1.5 \mu \mathrm{g} / \mathrm{ml} \mathrm{DEX}$ for $48 \mathrm{~h}$. Compared with that in the control group, the morphology of the CEM-C1 cells changed to round shapes and no notable reduction in cell viability. CEM-C7 cells showed plenty of cell fragments and cell death were apparent, as shown by the black arrows. Magnification, $\mathrm{x} 400$. DEX, dexamethasone.

and the autophagy-related gene, LC3, were detected using SYBR $^{\circledR}$-Green I Supermix (Toyobo Life Science), according to the manufacturer's instructions. The primer sequences are shown in Table I. The thermocycling conditions were as follows: Initial denaturation at $95^{\circ} \mathrm{C}$ for $30 \mathrm{sec}$, followed by 40 cycles of $95^{\circ} \mathrm{C}$ for $5 \mathrm{sec}, 60^{\circ} \mathrm{C}$ for $10 \mathrm{sec}$ and $72^{\circ} \mathrm{C}$ for $30 \mathrm{sec}$. Using GAPDH as the internal reference gene, the relative expression levels of the target genes were expressed using the $2^{-\Delta \Delta \mathrm{Cq}}$ method (28). The experiment was repeated 3 times.

Cell cycle analysis using flow cytometry. The CEM-C1 and CEM-C7 cells, in the logarithmic growth phase, were seeded in a 6 -well culture plate $\left(3 \times 10^{5}\right.$ cells/well), cultured for $48 \mathrm{~h}$, then the cells were collected and washed with PBS solution. The supernatant was discarded and $500 \mu 170 \%$ cold ethanol was added. The cells were fixed overnight at $4{ }^{\circ} \mathrm{C}$. Prior to staining, the ethanol was removed and the cells were washed with PBS and centrifuged at $300 \mathrm{x}$ g at $4^{\circ} \mathrm{C}$ for $5 \mathrm{~min}$. A total of $500 \mu \mathrm{l} \mathrm{PI} / \mathrm{RNase} \mathrm{A}$ staining working solution was added to each well. The samples were protected from light and incubated at room temperature for $30 \mathrm{~min}$. The red fluorescence was examined at an excitation wavelength of $488 \mathrm{~nm}$. The experimental groups were the same as those in the aforementioned RT-qPCR subheading.

Detection of cell apoptosis using flow cytometry. The CEM-C1 and CEM-C7 cells, in the logarithmic growth phase, were seeded in a 6 -well culture plate $\left(3 \times 10^{5}\right.$ cells/well $)$, cultured for $48 \mathrm{~h}$, then the cells were collected, washed twice with cold PBS and finally resuspended with $1 \mathrm{X}$ binding buffer, to adjust the cell density to $1 \times 10^{6}$ cells $/ \mathrm{ml}$. A total of $100 \mu \mathrm{l}$ cell suspension was used in a $5 \mathrm{ml}$ flow cytometer tube and $5 \mu \mathrm{lPI}$ 
A

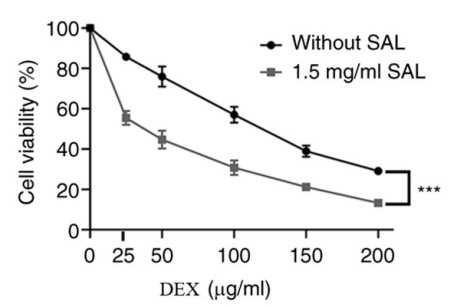

CEM-C7

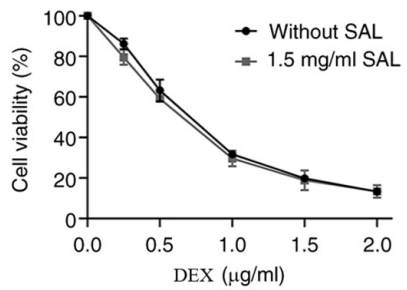

B

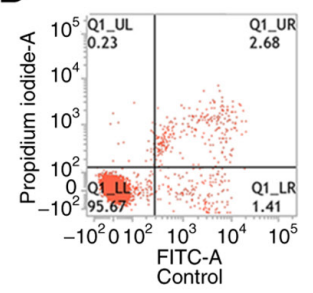

CEM-C1
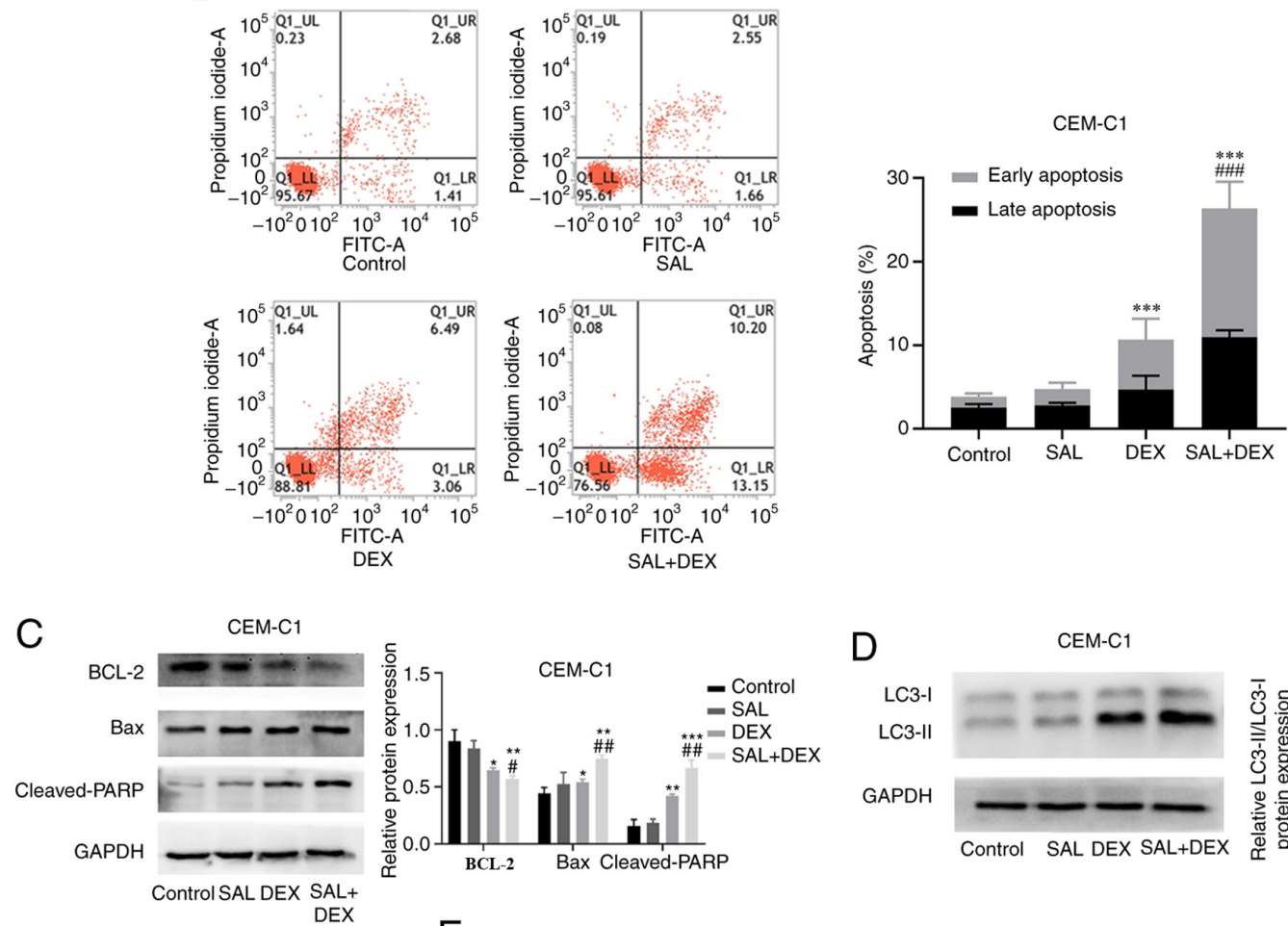

D
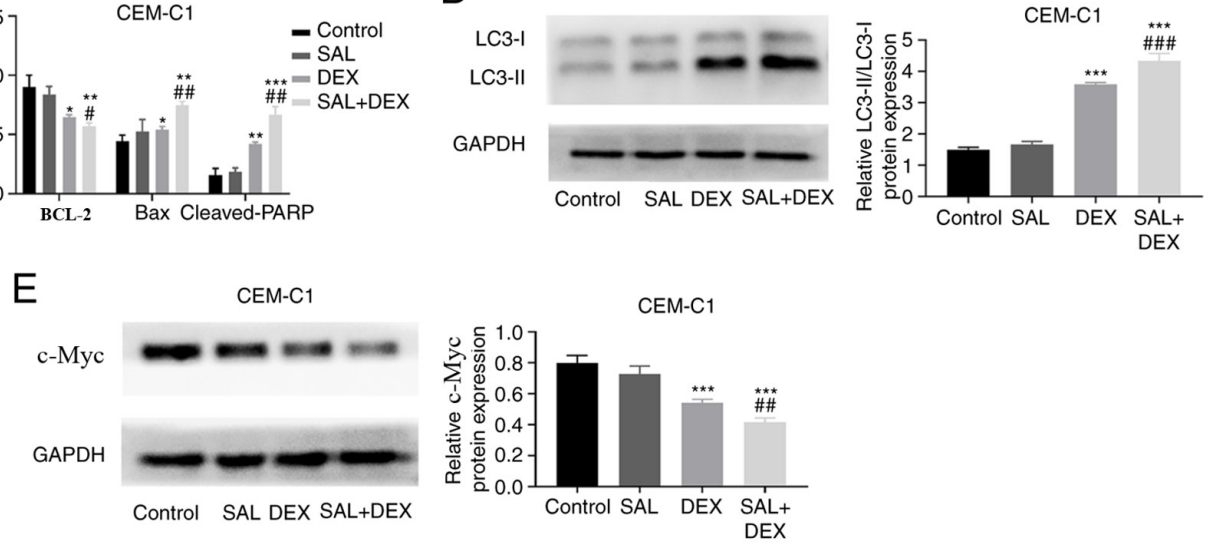

Figure 3. SAL enhances the chemosensitivity of the CEM-C1 cells to DEX. (A) The CEM-C1 and CEM-C7 cells were treated with DEX at various concentrations alone or in combination with $1.5 \mathrm{mg} / \mathrm{ml} \mathrm{SAL}$ for $48 \mathrm{~h}$, then cell viability was determined using a Cell Counting Kit- 8 assay. The data are presented as the mean \pm SD. ${ }^{* * *} \mathrm{P}<0.001$. (B) Flow cytometry using annexin V/PI staining was used to determine the rate of apoptosis after the cells were treated with $1.5 \mathrm{mg} / \mathrm{ml}$ SAL, $100 \mu \mathrm{g} / \mathrm{ml}$ DEX or in combination. ${ }^{* * *} \mathrm{P}<0.001$ vs. control group. ${ }^{\# \# *} \mathrm{P}<0.001$ vs. DEX group. (C) The expression level of the apoptotic-associated proteins in the CEM-C1 cells following treatment with $1.5 \mathrm{mg} / \mathrm{ml} \mathrm{SAL}, 100 \mu \mathrm{g} / \mathrm{ml} \mathrm{DEX}$ or in combination. ${ }^{*} \mathrm{P}<0.05,{ }^{* * *} \mathrm{P}<0.01,{ }^{* * * *} \mathrm{P}<0.001 \mathrm{vs}$. control group. ${ }^{\#} \mathrm{P}<0.05,{ }^{\# \#} \mathrm{P}<0.01$ vs. DEX group. (D) The protein expression level of LC3 in the CEM-C1 cells following treatment with $1.5 \mathrm{mg} / \mathrm{ml} \mathrm{SAL}, 100 \mu \mathrm{g} / \mathrm{ml} \mathrm{DEX}$ or in combination. ${ }^{* * *} \mathrm{P}<0.001$ vs. control group. ${ }^{\# \# /} \mathrm{P}<0.001$ vs. DEX group. (E) The protein expression level of c-Myc in the CEM-C1 cells following treatment with $1.5 \mathrm{mg} / \mathrm{ml} \mathrm{SAL}$ and $100 \mu \mathrm{g} / \mathrm{ml}$ DEX or in combination. ${ }^{* * *} \mathrm{P}<0.001$ vs. control group. ${ }^{\# \#} \mathrm{P}<0.01$ vs. DEX group. SAL, salidroside; DEX, dexamethasone.

was mixed with $5 \mu$ l Annexin V-FITC and added to the cells. The samples were shaken and placed at room temperature for $25 \mathrm{~min}$ in the dark. Subsequently, $200 \mu \mathrm{l} 1 \mathrm{X}$ binding buffer was added to the cells, and measured using flow cytometry within $1 \mathrm{~h}$. The experiment was repeated 3 times. The experimental groups were the same as those in the aforementioned RT-qPCR subheading. Additionally, according to whether SAL was combined with DEX, CEM-C1 cells were divided into control group, SAL group $(1.5 \mathrm{mg} / \mathrm{ml})$, DEX group $(100 \mu \mathrm{g} / \mathrm{ml})$ and combination group (DEX $100 \mu \mathrm{g} / \mathrm{ml}+\mathrm{SAL}$ $1.5 \mathrm{mg} / \mathrm{ml})$.
Western blot analysis. The CEM-C1 and CEM-C7 cells, in the logarithmic growth phase, were seeded into a 6-well culture plate $\left(5 \times 10^{6}\right.$ cells/well $)$ and the total protein from each group was extracted $48 \mathrm{~h}$ later using RIPA lysis buffer (Beyotime Institute of Biotechnology) for $30 \mathrm{~min}$ and the total protein concentration was determined using the BCA method. A total of $25 \mu \mathrm{g}$ total protein was extracted and analyzed using SDS-PAGE, transferred to a PVDF membrane, blocked with $7 \%$ skimmed milk at room temperature for $1 \mathrm{~h}$ and incubated with the following primary antibodies anti-GAPDH $(1: 15,000$ dilution; cat. no. 10494-1-AP), anti-Bax (1:1,000 dilution; 

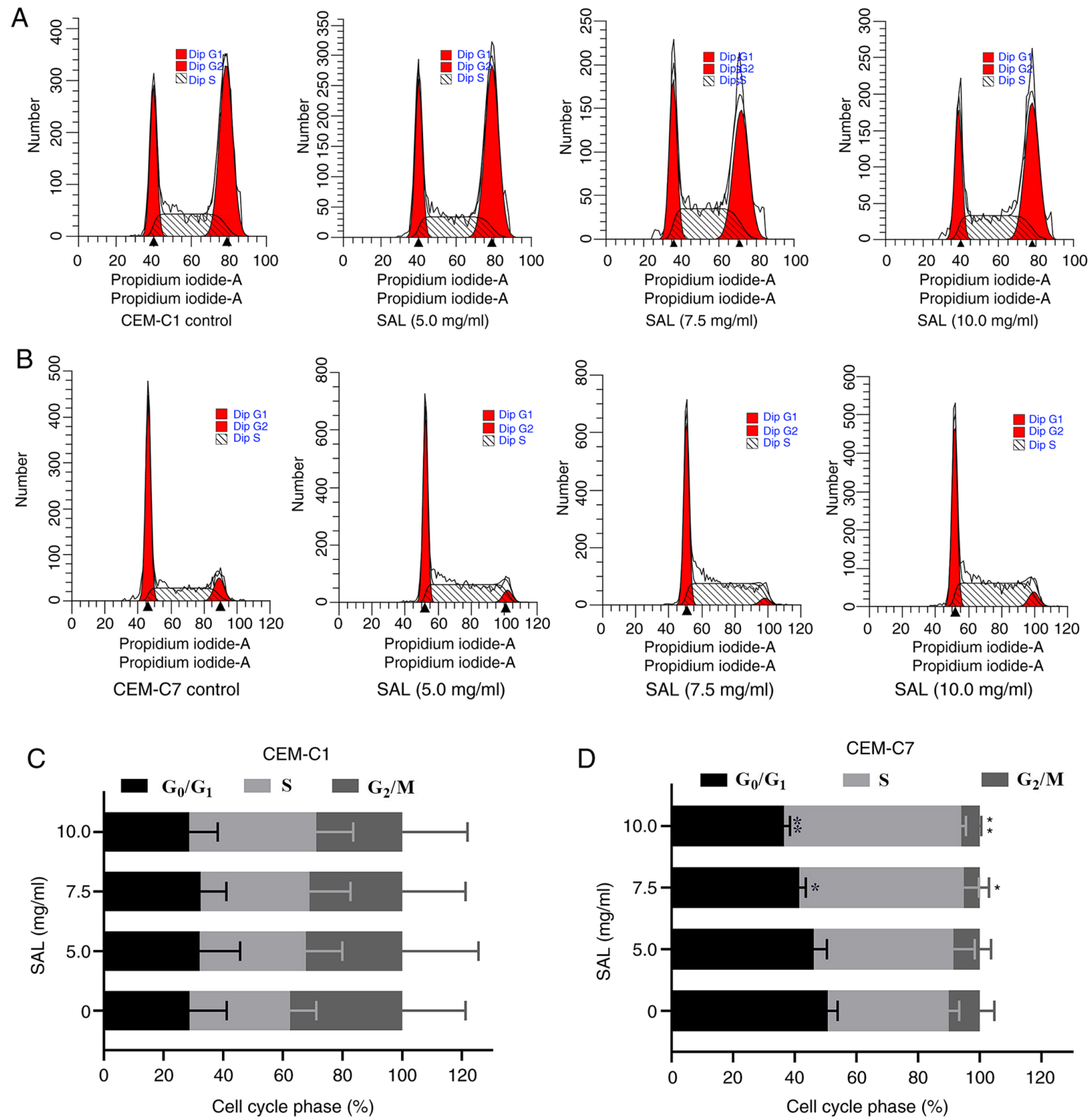

Figure 4. Effects of SAL on cell cycle progression. Flow cytometry was used to detect the cell cycle distribution following treatment of the (A) CEM-C1 and the (B) CEM-C7 cells with SAL (0, 5.0, 7.5 or $10.0 \mathrm{mg} / \mathrm{ml})$ for $48 \mathrm{~h}$, and the data was subsequently (C and D) quantified, respectively. The data are presented as the mean $\pm \mathrm{SD} .{ }^{*} \mathrm{P}<0.05,{ }^{* *} \mathrm{P}<0.01$ vs. control group. $\mathrm{SAL}$, salidroside.

cat. no. 5023), anti-BCL-2 (1:1,000 dilution; cat. no. 4223), anti-cleaved-PARP (1:1,000 dilution; cat. no. 9185), anti-LC3A/B (1:1,000 dilution; cat. no. 12741) and anti-c-Myc (1:2,000 dilution; cat. no. 10828-1-AP) overnight at $4^{\circ} \mathrm{C}$. The membrane was washed 3 times with PBS with $0.07 \%$ Tween-20 (PBST), then the secondary antibody (HRP-labeled goat anti-rabbit antibody; 1:2,000; cat. no. bs-0295G-HRP) was added and the membrane was incubated for $1 \mathrm{~h}$ at room temperature. The membrane was washed with PBST three times and developed using an enhanced chemiluminescence kit (EMD Millipore). The protein expression level was measured using densitometry of the bands with ImageJ v1.4.3.67 (National Institute of Health). The protein expression levels were normalized to GAPDH. The experiments were repeated three times. The experimental groups were the same as those in the aforementioned RT-qPCR subheading. Additionally, according to whether SAL was combined with DEX, CEM-C1 cells were divided into control group, SAL group $(1.5 \mathrm{mg} / \mathrm{ml})$, DEX group $(100 \mu \mathrm{g} / \mathrm{ml})$ and combination group (DEX $100 \mu \mathrm{g} / \mathrm{ml}+$ SAL $1.5 \mathrm{mg} / \mathrm{ml}$ ).

Acridine orange staining. The CEM-C1 and CEM-C7 cells, in the logarithmic growth phase, were seeded in a 6-well culture plate $\left(3 \times 10^{5}\right.$ cells/well), cultured for $48 \mathrm{~h}$, then washed with PBS, and stained with acridine orange staining solution $(10 \mu \mathrm{g} / \mathrm{ml})$ for $30 \mathrm{~min}$ in the dark at room temperature. The cells were observed and images were captured using a fluorescence microscope (magnification, $\mathrm{x} 400$ ). The experimental groups were the same as those in the aforementioned RT-qPCR subheading. 
A
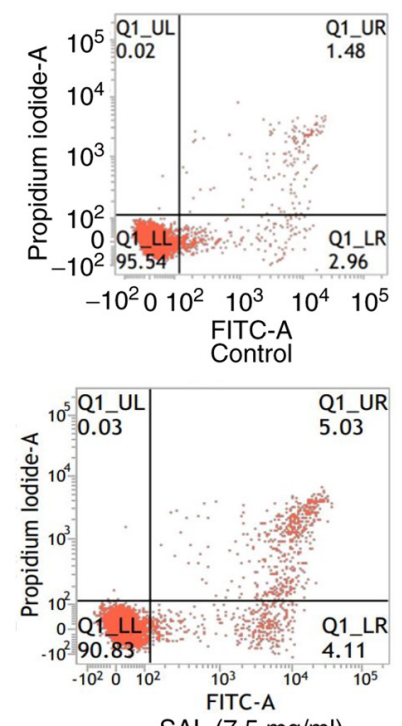

$\operatorname{SAL}(7.5 \mathrm{mg} / \mathrm{ml})$
CEM-C1
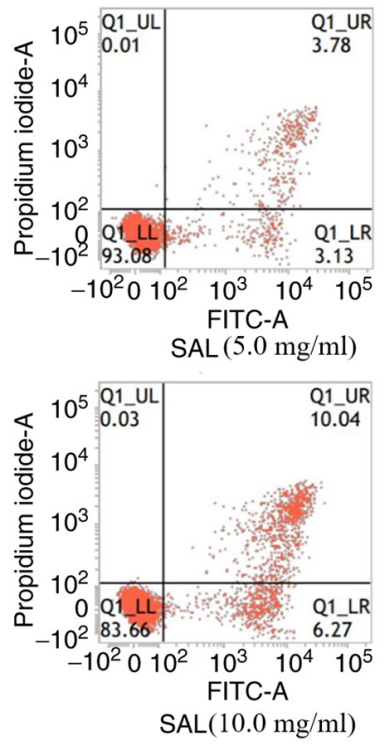

B

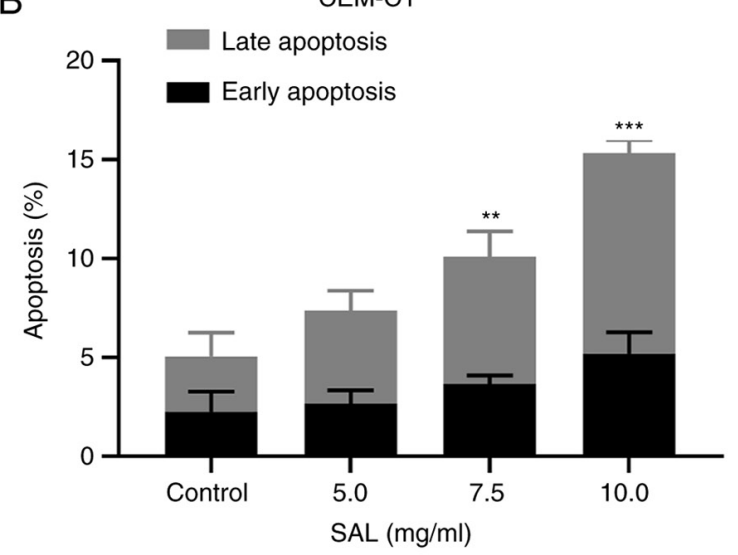

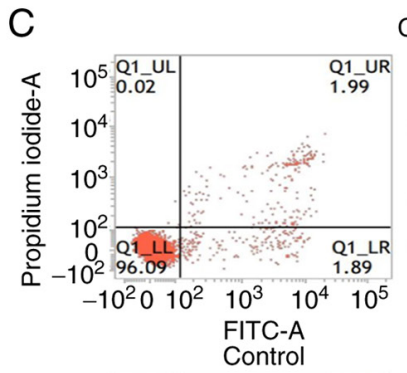

CEM-C7
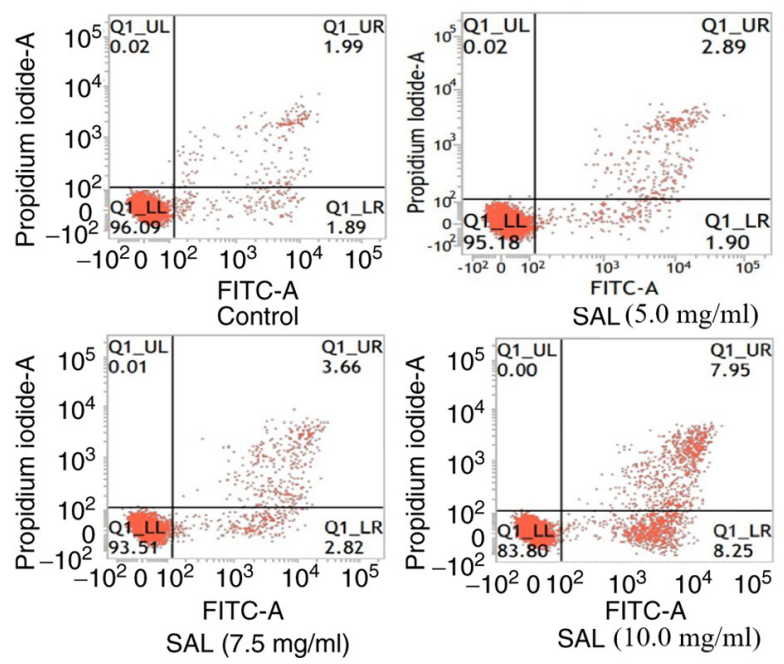

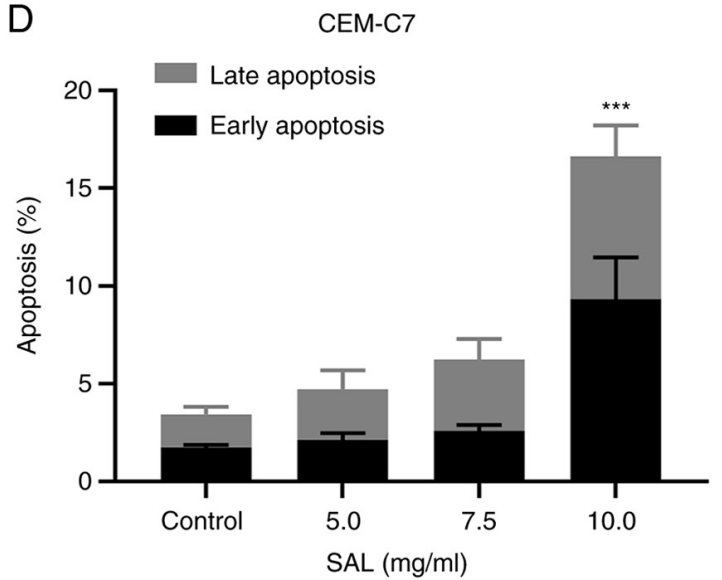

Figure 5. Effect of SAL on the rate of apoptosis in the CEM-C1 and CEM-C7 cells. (A) The CEM-C1 cells were treated with different concentrations of SAL for $48 \mathrm{~h}$ and subsequently analyzed using flow cytometry using Annexin V-FITC/PI, then (B) statistically analyzed. (C) The CEM-C7 cells were treated with different concentrations of SAL for $48 \mathrm{~h}$ and subsequently analyzed using flow cytometry, then (D) statistically analyzed. The data are presented as the mean \pm SD. ${ }^{* *} \mathrm{P}<0.01,{ }^{* * *} \mathrm{P}<0.001$ vs. control group. SAL, salidroside.

Statistical analysis. The SPSS v23.0 software (IBM Corp.) was used for data analysis. The quantitative data are presented as the mean \pm SD. Comparisons between two groups was performed using an independent Student's t-test, while one-way ANOVA was used for the comparison of multiple groups. Tukey's post hoc test was used when the homogeneity of variance was equal, while the Tamhane's T2 test was used when the variance was unequal. $\mathrm{P}<0.05$ was considered to indicate a statistically significant difference.

\section{Results}

SAL inhibits the proliferation of the T-ALL cells. To investigate the anti-proliferative activity of SAL on the T-ALL cells, cell proliferation was determined using a CCK8 assay. As depicted in Fig. 1A, SAL effectively inhibited the proliferation of the CEM-C1 and CEM-C7 cells in a dose-and time-dependent manner. $\mathrm{The} \mathrm{IC}_{50}$ of the CEM-C1 cells at 24,48 and $72 \mathrm{~h}$ was $11.26,6.69$ and $6.45 \mathrm{mg} / \mathrm{ml}$, respectively, while the $\mathrm{IC}_{50}$ of the CEM-C7 cells at 24,48 and $72 \mathrm{~h}$ was $11.42,8.03$ and $7.73 \mathrm{mg} / \mathrm{ml}$, respectively (data not shown). No significant difference was found in the $\mathrm{IC}_{50}$ values between the 48 and $72 \mathrm{~h}$ time points $(\mathrm{P}>0.05)$. Based on this finding, $48 \mathrm{~h}$ was selected as the intervention time point. In subsequent experiments, different concentrations of SAL $(5.0,7.5$ and $10.0 \mathrm{mg} / \mathrm{ml})$ to treat the cells were selected to detect the effect on cell cycle, apoptosis, and autophagy. The results also showed that SAL was more effective at inhibiting CEM-C1 cell viability compared with that in the CEM-C7 cells, which indicated that the DEX-resistant cells were more sensitive to SAL, as shown in Fig. 1B. 
A

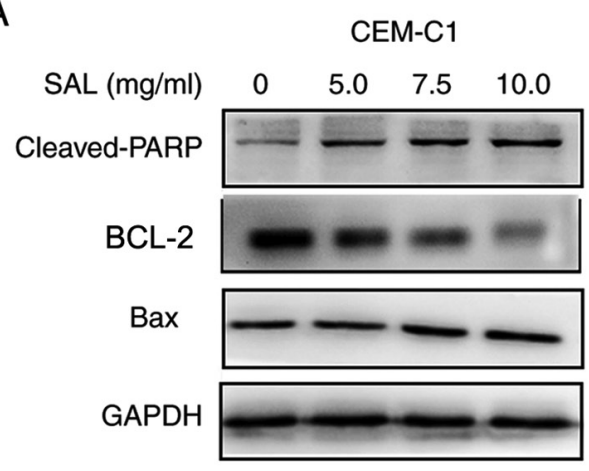

C

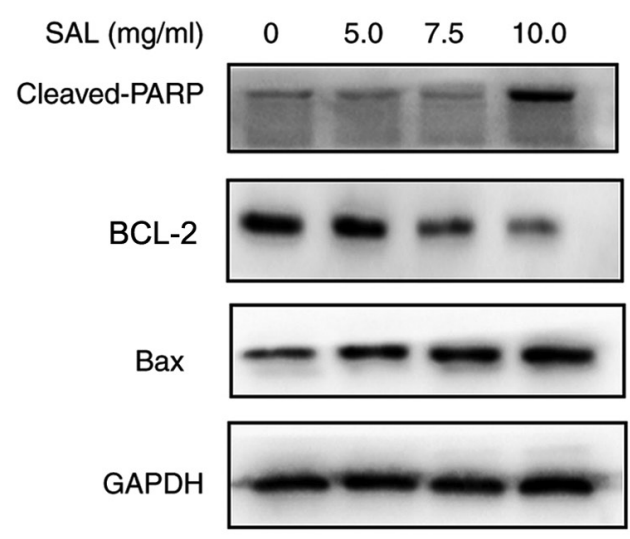

B

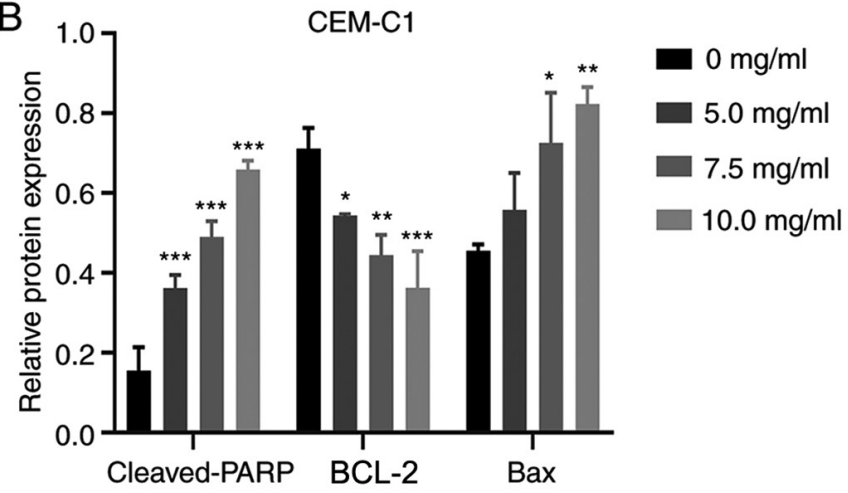

$\mathrm{D}$

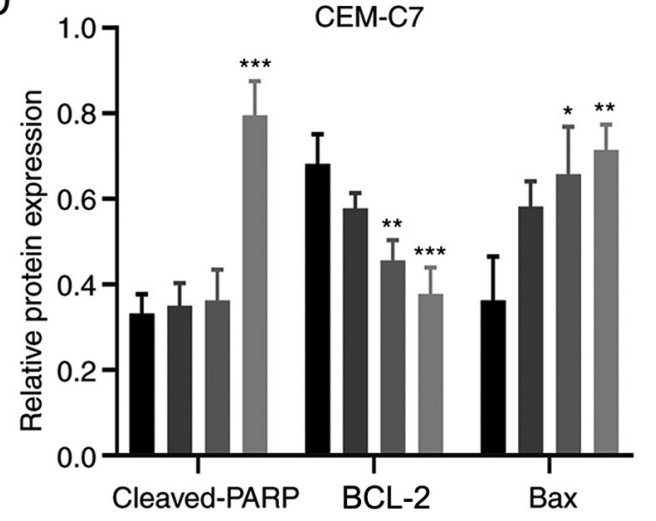

$0 \mathrm{mg} / \mathrm{ml}$

$5.0 \mathrm{mg} / \mathrm{ml}$

$7.5 \mathrm{mg} / \mathrm{ml}$

$10.0 \mathrm{mg} / \mathrm{ml}$

Figure 6. Effect of SAL on the expression of the apoptotic-associated proteins in the CEM-C1 and CEM-C7 cells. (A) Western blot analysis was used to determine the relative expression levels of the apoptotic-associated proteins in the CEM-C1 cells, then the data was (B) quantitatively analyzed. (C) Western blot analysis was used to determine the relative expression levels of the apoptotic-associated proteins in the CEM-C7 cells, then (D) quantitatively analyzed. The data are presented as the mean $\pm \mathrm{SD} .{ }^{*} \mathrm{P}<0.05,{ }^{* *} \mathrm{P}<0.01,{ }^{* * *} \mathrm{P}<0.001$ vs. control group. SAL, salidroside.

Effect of DEX on the morphology of the CEM-C1 and CEM-C7 cells. The CEM-C1 and CEM-C7 cells were treated with $1.5 \mu \mathrm{g} / \mathrm{ml} \mathrm{DEX}$ for $48 \mathrm{~h}$ and cellular morphology was assessed using a light microscope. As shown in Fig. 2, the morphology of the DEX-resistant, CEM-C1 cells changed from slender and irregular shapes to round shapes and no notable reduction in cell viability was noted using microscopy compared with that in the control group. However, the DEX-sensitive CEM-C7 cells showed a large number of cell fragments and increased cell death compared with that in the control cells. It was suggested that CEM-C1 cells exhibited strong resistance to DEX.

SAL enhances the sensitivity of the CEM-C1 cells to DEX. To verify the resistance of the CEM-C1 cells to DEX, the cytotoxic effect of DEX on DEX-sensitive CEM-C7 cells and DEX-resistant CEM-C1 cells was determined using a CCK-8 assay. Fig. 3A demonstrated that the $\mathrm{IC}_{50}$ in the CEM-C1 and CEM-C7 cells, treated with DEX and without SAL was $111.83 \pm 2.87$ and $0.67 \pm 0.02 \mu \mathrm{g} / \mathrm{ml}$, respectively, whereas the RI was 166.92 (data not shown). Our preliminary drug concentration screening results showed that the cell proliferation inhibition rate on the CEM-C1 and CEM-C7 cells treated with $1.5 \mathrm{mg} / \mathrm{ml} \mathrm{SAL}$ was <4\% (Fig. S1). Therefore, $1.5 \mathrm{mg} / \mathrm{ml} \mathrm{SAL}$ was selected, combined with DEX, to culture the cells for $48 \mathrm{~h}$. Fig. S2A indicated that the $\mathrm{IC}_{50}$ in the CEM-C1 cells treated with
$\mathrm{DEX}+\mathrm{SAL}$ was significantly decreased to $35.59 \pm 3.73 \mu \mathrm{g} / \mathrm{ml}$. The RF was 3.14 (data not shown). In contrast to this finding, the DEX + SAL group exhibited no significant effect on the $\mathrm{IC}_{50}$ value in the CEM-C7 cells compared with that in the cells treated with DEX alone (Fig. S2B; P>0.05).

To determine whether SAL could enhance the sensitivity of the CEM-C1 cells to DEX, the CEM-C1 cells were treated with $\operatorname{SAL}(1.5 \mathrm{mg} / \mathrm{ml})$, DEX $(100 \mu \mathrm{g} / \mathrm{ml})$ or in combination for $48 \mathrm{~h}$. Flow cytometry analysis showed that a combination of SAL and DEX increased the apoptotic rate of the CEM-C1 cells from 10.65 to $26.35 \%$ compared with that in the DEX only group (Fig. 3B). Subsequently, western blot analysis showed that the combination treatment induced the activation of cleaved-PARP and Bax, and decreased the protein expression of BCL-2 (Fig. 3C). Notably, in the combination treatment group, there was also a significant increase in LC3 protein expression level when compared with that in the DEX or SAL only groups (Fig. 3D). Furthermore, Fig. 3E showed that the DEX alone group inhibited the protein expression level of c-Myc in the CEM-C1 cells and the combination of the two drugs was the most effective and statistically significant. The data suggested that SAL increased the sensitivity of the CEM-C1 cells to DEX.

Effect of SAL on the cell cycle in T-ALL cells. To investigate whether SAL could affect the cell cycle in the T-ALL cells, the 
A

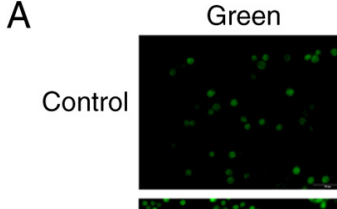

$(5 \mathrm{mg} / \mathrm{ml})$
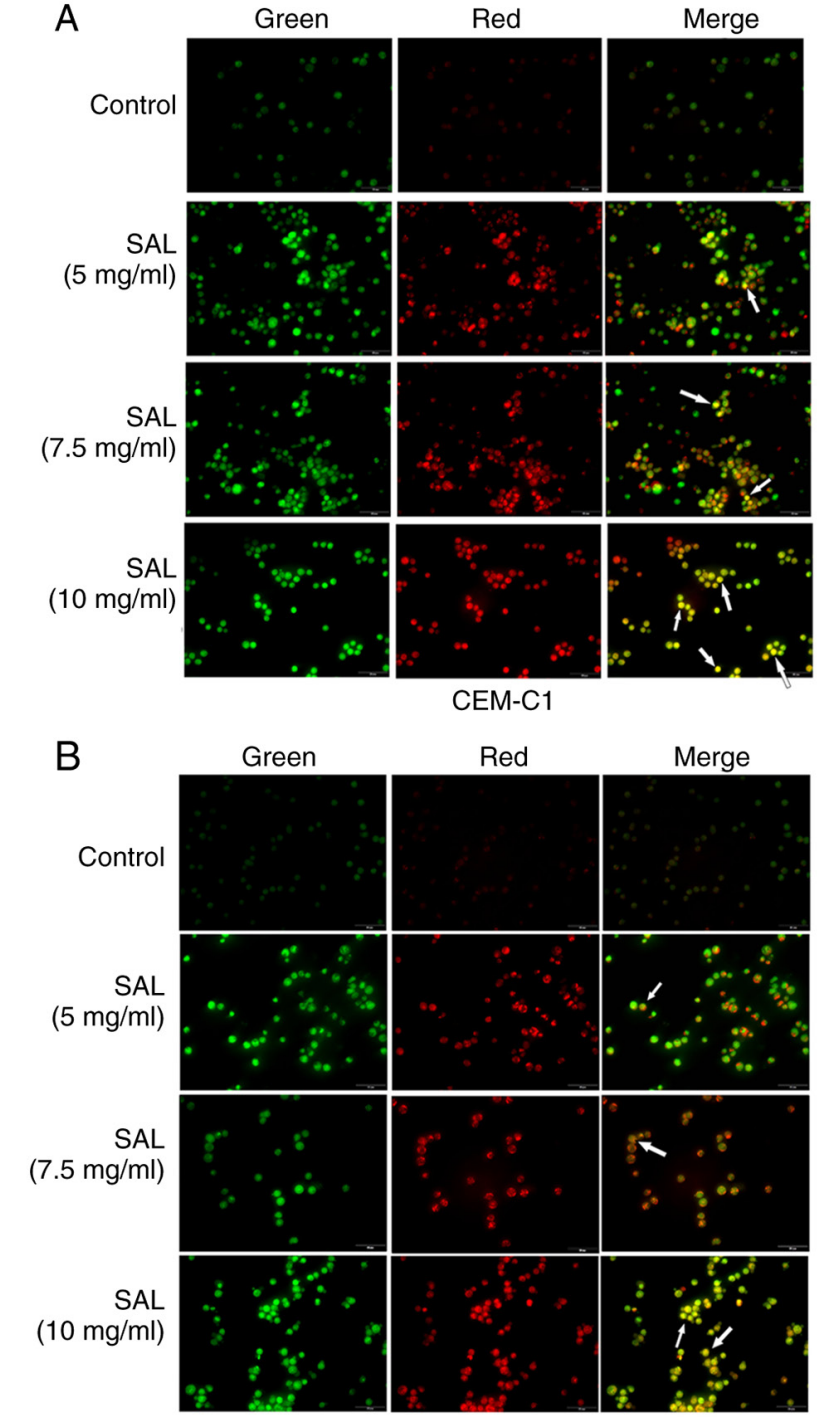

CEM-C1

CEM-C7

Figure 7. Acridine orange staining for the detection of autophagy in the CEM-C1 and CEM-C7 cells. The (A) CEM-C1 and (B) CEM-C7 were treated with different concentrations of SAL then stained with acridine orange. Green fluorescence indicates staining of the nucleoli and the cytoplasm, while red fluorescence indicates staining of the autophagic lysosomes and orange fluorescence indicates staining of the acidic autophagy vesicles (white arrows). Magnification, x400. SAL, salidroside.

CEM-C1 and CEM-C7 cell lines were treated with different concentrations of SAL for $48 \mathrm{~h}$ and subsequently stained with PI (Fig. 4A and B). Following an increase in SAL concentration, the percentage of the cells in the $\mathrm{G}_{0} / \mathrm{G}_{1}$ phase in the CEM-C7 cells was significantly decreased $(\mathrm{F}, 11.93$; $\mathrm{P}<0.01)$, whereas the percentage of the cells in the $\mathrm{S}$ phase was significantly increased $(\mathrm{F}, 9.30 ; \mathrm{P}<0.01)$. No significant change was noted with respect to the $G_{2} / M$ phase $(P>0.05)$, indicating that $S A L$ blocked the CEM-C7 cells in the S phase (Fig. 4D). However, SAL exhibited no significant difference in the cell cycle of the CEM-C1 cells ( $\mathrm{P}>0.05$; Fig. 4C).

Effect of SAL on the induction of apoptosis in the T-ALL cells. To investigate whether SAL could induce apoptosis in the T-ALL cells, the CEM-C1 and CEM-C7 cell lines were treated with SAL at different concentrations. The results indicated that
SAL could increase the early, late and total apoptotic rate of the CEM-C1 and CEM-C7 cells (Fig. 5A and C). Following an increase in the concentration of SAL, CEM-C1 cells underwent apoptosis. The total apoptotic rate was significantly increased from $5.06 \pm 0.66 \%$ in the control group to $10.18 \pm 0.87 \%$ in cells treated with $7.5 \mathrm{mg} / \mathrm{ml} \mathrm{SAL}(\mathrm{P}<0.01)$, whereas treatment with $10.0 \mathrm{mg} / \mathrm{ml} \mathrm{SAL}$ increased the total apoptotic rate to $15.34 \pm 1.45 \%$, which was significantly higher compared with that in the control group $(\mathrm{P}<0.001$; Fig. 5B). In the CEM-C7 cells, the total apoptotic rate following $10.0 \mathrm{mg} / \mathrm{ml} \mathrm{SAL}$ treatment was $16.62 \pm 3.44 \%$, which was significantly higher compared with that in the control group $3.43 \pm 0.46 \%(\mathrm{P}<0.001$; Fig. 5D). This suggested that SAL could induce apoptosis in the human T-ALL cell lines.

Effect of SAL on the expression level of apoptosis-associated proteins. To further investigate the molecular mechanism of SAL in promoting apoptosis of the T-ALL cell lines, the expression level of the pro-apoptotic and anti-apoptotic proteins was determined. Western blot analysis indicated that there was an increase in the expression levels of Bax and cleaved-PARP proteins following treatment with different concentrations of SAL. There was also inhibition in the protein expression level of BCL-2 in the CEM-C1 and CEM-C7 cells, in a dose-dependent manner (Fig. 6).

SAL induces autophagy in the T-ALL cells. Autophagy is characterized by the formation of acidic autophagy vesicles in the cells and can be determined using acridine orange staining (29). Acridine orange is a fluorescent dye used for detecting the structure of acid vesicles that produces green fluorescence following binding to the nucleoli and the cytoplasm, and red fluorescence following binding to autophagic lysosomes (30). The results of acridine orange staining indicated that the number of orange fluorescent organelles in the CEM-C1 and CEM-C7 cells, corresponding to the number of acidic autophagy vesicles, was notably increased compared with that in the control group. This suggested that SAL promoted autophagy in the human T-ALL cell lines (Fig. 7A and B).

Effect of SAL on autophagy-related protein expression levels. During the process of autophagy, LC3 is the membrane component of the autophagosome extension and LC3 is converted from LC3-I to LC3-II (31). Therefore, LC3-II can be used to quantify the number of intracellular autophagosomes (32). The results of western blot analysis showed that compared with that in the control group, the expression levels of the LC3-II protein in the CEM-C1 and CEM-C7 cells was significantly increased, and the protein expression ratio of LC3-II/LC3-I was also increased (F, 77.64 and 73.88, respectively, with $10.0 \mathrm{mg} / \mathrm{ml} \mathrm{SAL}$; both $\mathrm{P}<0.001$; Fig. 8A-D). The mRNA expression level of LC3 was also found to be upregulated (F, 19.11 and 37.49, with $10.0 \mathrm{mg} / \mathrm{ml}$ SAL; $\mathrm{P}<0.05$; Fig. $8 \mathrm{E}$ and $\mathrm{F}$ ). This suggested that $\mathrm{SAL}$ could induce autophagy in the human T-ALL cell lines, CEM-C1 and CEM-C7.

Protein expression of $c-M y c$ in the DEX-resistant CEM-C1 cells. To investigate the role of c-Myc in the DEX-resistant 
A

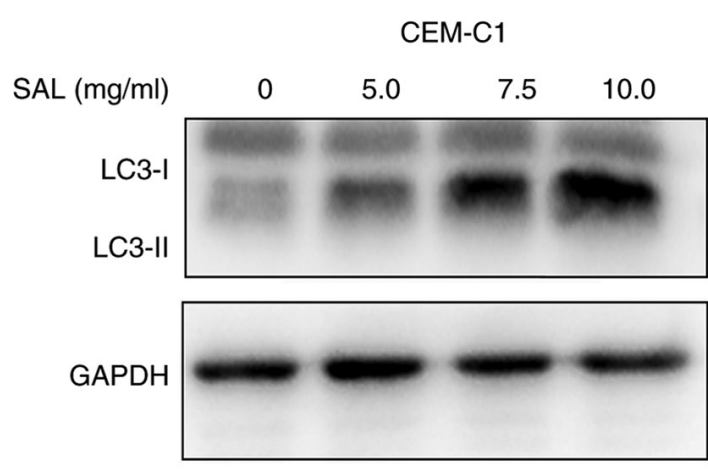

C

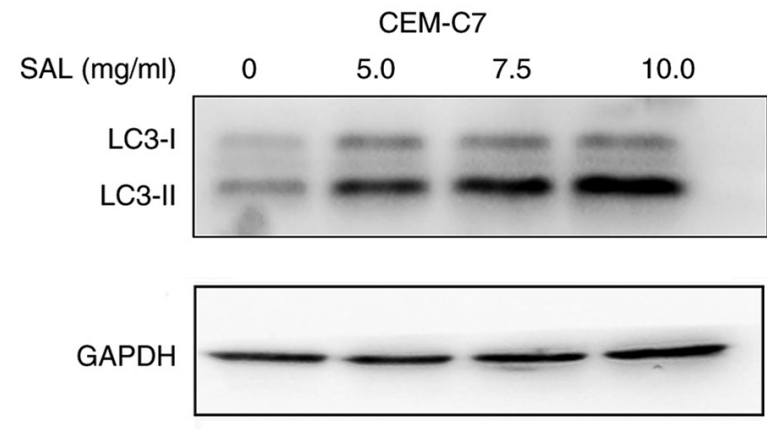

$\mathrm{E}$

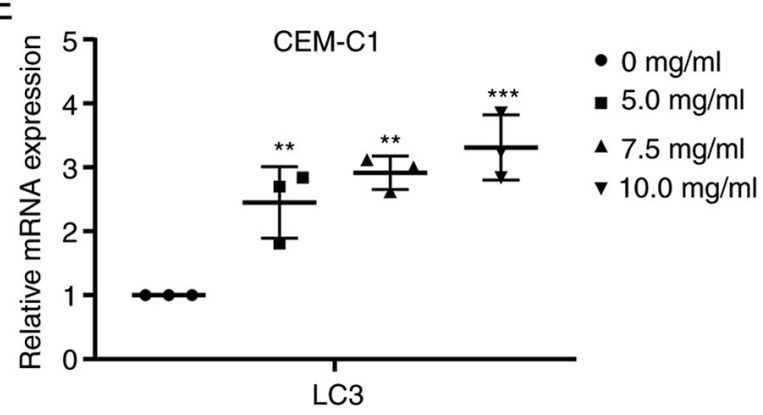

$\mathrm{B}$

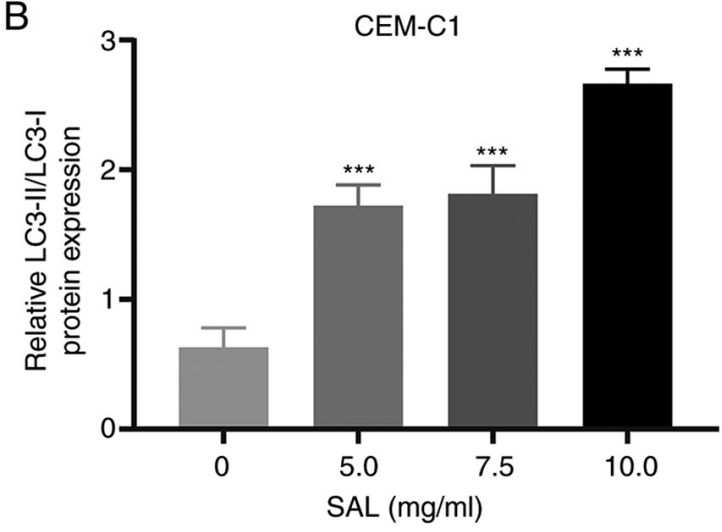

CEM-C7

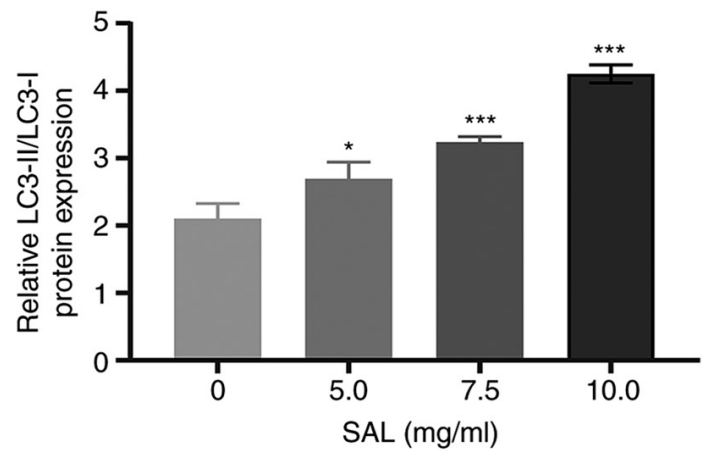

$\mathrm{F}$

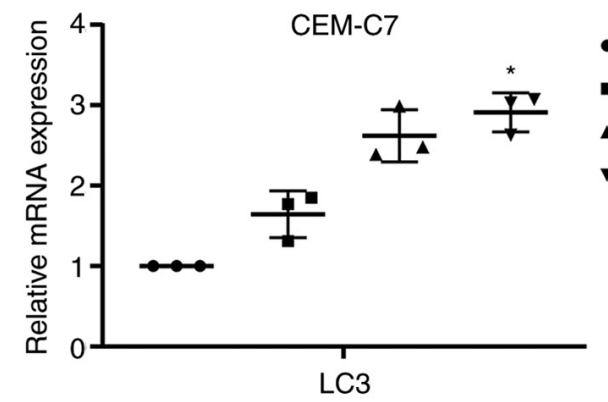

- $0 \mathrm{mg} / \mathrm{ml}$

- $5.0 \mathrm{mg} / \mathrm{ml}$

\ $7.5 \mathrm{mg} / \mathrm{ml}$

$\checkmark 10.0 \mathrm{mg} / \mathrm{ml}$

Figure 8. Western blot analysis and reverse transcription-quantitative PCR was used to detect the protein and mRNA expression level of autophagy-related proteins in the CEM-C1 and CEM-C7 cells following SAL treatment. (A) The effects of SAL on LC3 protein expression level in the CEM-C1 cells following treatment with various concentrations of SAL for $48 \mathrm{~h}$, then the results were (B) quantified. (C) The effects of SAL on LC3 protein expression level in the CEM-C7 cells following treatment with SAL at various concentrations for $48 \mathrm{~h}$, then the data was subsequently (D) analyzed. Relative LC3 mRNA expression level in the (E) CEM-C1 and (F) CEM-C7 cells. The data are presented as the mean $\pm \mathrm{SD}$. ${ }^{*} \mathrm{P}<0.05,{ }^{* * *} \mathrm{P}<0.01,{ }^{* * *} \mathrm{P}<0.001$ vs. control group. SAL, salidroside.

CEM-C1 cells, western blot analysis was used to detect the expression levels of the c-Myc protein in the CEM-C1 and CEM-C7 cells. The results indicated that the CEM-C1 cells expressed higher c-Myc protein levels compared with that in the CEM-C7 cells (Fig. 9A and B). High expression of c-Myc may reduce the sensitivity of the CEM-C1 cells to DEX, indicating that c-Myc could play an important role in the occurrence and development of tumor drug resistance.

SAL overcomes DEX-resistance in the CEM-Cl cells by downregulating $c-M y c$ protein and $m R N A$ expression. Various studies have shown that high mRNA expression of c-Myc has been associated with drug resistance in pancreatic cancer and HPV-negative neck squamous cell carcinoma cells $(33,34)$. It has also been shown that downregulation of c-Myc mRNA expression using siRNA could improve the efficacy of DEX in treatment of ALL (35). To investigate the mechanism in which the CEM-C1 cells could overcome DEX resistance following treatment with SAL, the CEM-C1 and CEM-C7 cells were treated with different concentrations of SAL for $48 \mathrm{~h}$, and the protein and mRNA expression levels of c-Myc were determined. Western blot analysis indicated that the c-Myc protein expression level was decreased in a dose-dependent manner, in both cells, compared with that in the control group (F, 21.74 and 18.58, with $10.0 \mathrm{mg} / \mathrm{ml} \mathrm{SAL}$; $<<0.001$; Fig. 10A-D). The RT-qPCR results indicated that the c-Myc mRNA expression levels were also decreased in a dose-dependent manner compared with that in the control group (F, 43.14 and 161.0, 
A

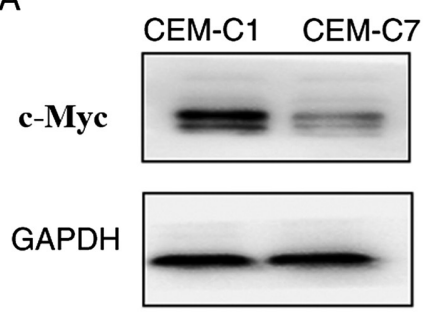

B

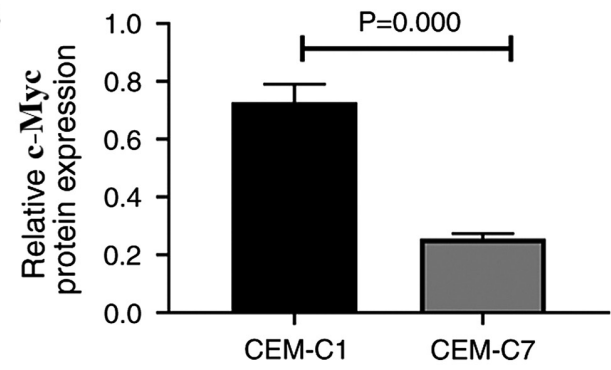

Figure 9. High protein and mRNA c-Myc expression level in the DEX-resistant cell line, CEM-C1 (A) Western blot analysis was used to analyze the protein expression level of c-Myc in the CEM-C1 and CEM-C7 cells, then the data was subsequently statistically (B) quantified.

A

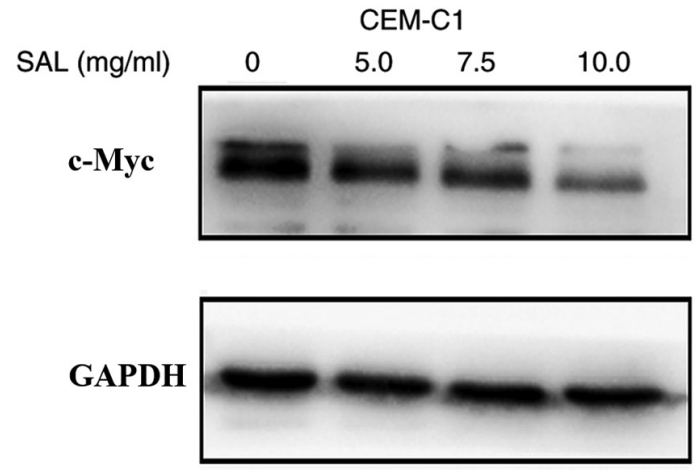

C

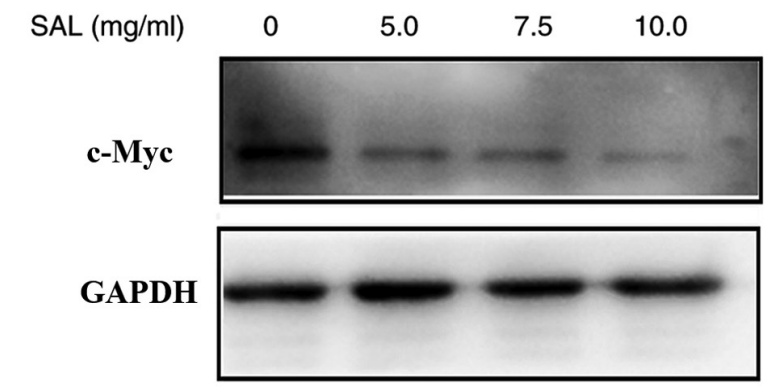

E

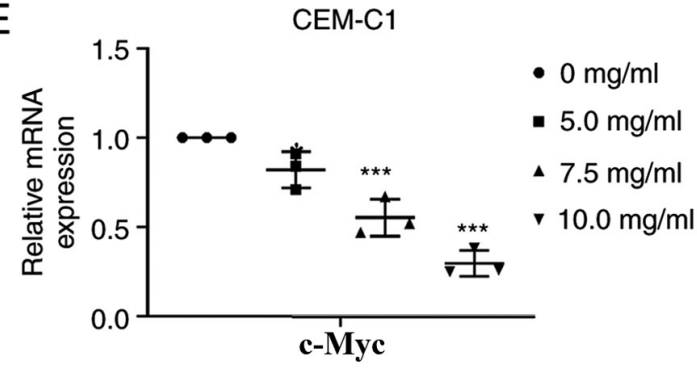

B

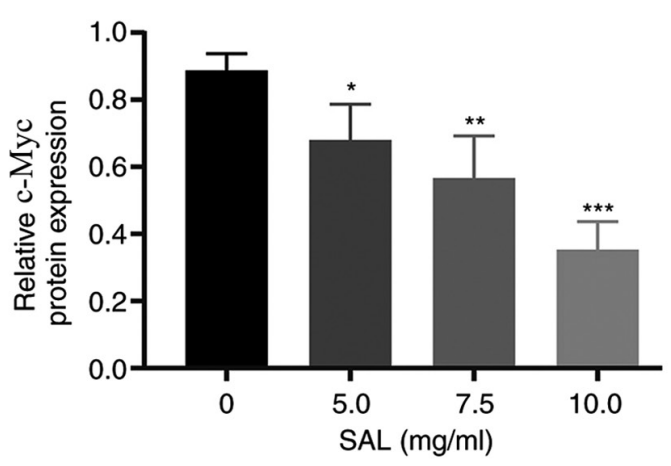

D

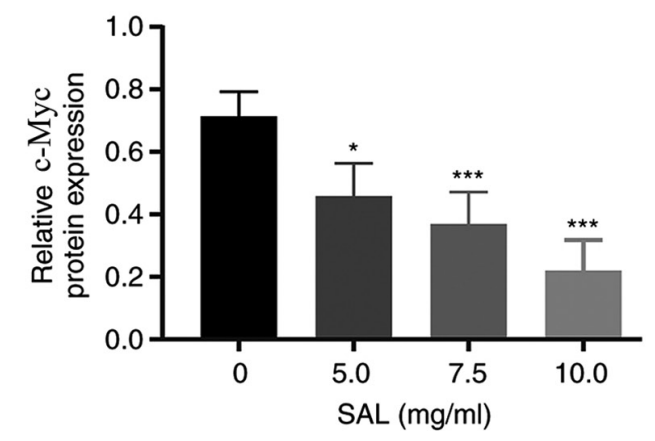

$\mathrm{F}$

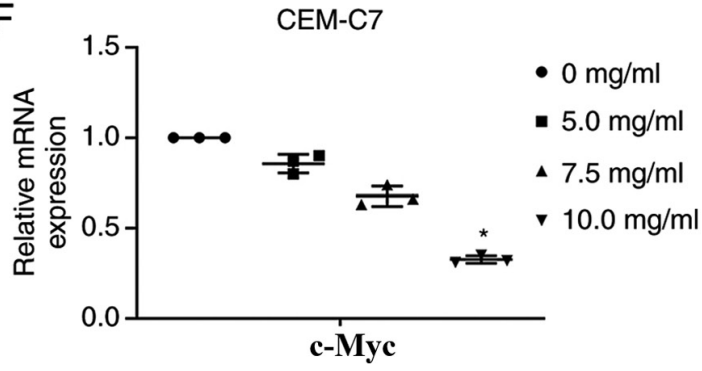

Figure 10. Effect of SAL on c-Myc protein and mRNA expression levels in the CEM-C1 and CEM-C7 cells. (A) The CEM-C1 cells were treated with different concentrations of SAL for $48 \mathrm{~h}$, then the c-Myc protein expression level was analyzed using western blot analysis, and the results were subsequently (B) quantified. (C) The CEM-C7 cells were treated with different concentrations of SAL for $48 \mathrm{~h}$, then the c-Myc protein expression level was analyzed using western blot analysis, and the results were subsequently (D) quantified. The relative c-Myc mRNA expression levels in the (E) CEM-C1 and (F) CEM-C7 cells following treatment with different concentrations of SAL. The data are presented as the mean $\pm \mathrm{SD}$. ${ }^{*} \mathrm{P}<0.05,{ }^{* *} \mathrm{P}<0.01,{ }^{* * *} \mathrm{P}<0.001$ vs. control group. SAL, salidroside.

with $10.0 \mathrm{mg} / \mathrm{ml} \mathrm{SAL}$; $<<0.05$; Fig. 10E and F). This suggested that SAL could reduce DEX resistance in the human T-ALL, CEM-C1 cells by downregulating c-Myc protein and mRNA expression.

\section{Discussion}

ALL is one of the most common malignancies, with the highest incidence rate in children, accounting for $\sim 80 \%$ of leukemia 
cases. ALL is five times more common than acute myeloid leukemia (36). ALL can be divided into B-ALL and T-ALL. DEX is a synthetic GC, which has been used to treat patients with T-ALL (37). At present, resistance to DEX is one of the important reasons leading to treatment failure or recurrence. Therefore, it is important to clarify the mechanism of DEX resistance and overcome it.

Tumor cells are characterized by unrestricted proliferation. The two main pathways of tumor cell death are apoptosis and autophagy. Cell apoptosis and autophagy have been associated with tumorigenesis and cancer prevention (38). A previous study has shown that dysregulation of apoptosis promoted the survival of malignant cells and reduced the sensitivity of tumor cells to specific drugs in leukemia (39). Autophagy is an important intracellular process that causes the degradation of unnecessary or damaged cytoplasmic contents to maintain metabolism and homeostasis (40). Autophagy exhibits a dual function by promoting cell survival and cell death, and has been associated with tumorigenesis, metastasis and drug resistance (41). The induction of apoptosis and autophagy is an effective antitumor therapy strategy $(42,43)$. Long et al (44) demonstrated that by promoting the induction of autophagy and apoptosis, this process could increase the sensitivity to GC treatment in human acute lymphoblastic leukemia cells.

SAL has been reported to have a wide range of pharmacological functions, including anti-tumor activity, that SAL-based activation of apoptosis and autophagy are the major mechanisms responsible for the anti-cancer activity of this compound (45). A previous study has shown that SAL induced apoptosis and autophagy in human colon cancer cells by inhibiting the PI3K/Akt/mTOR pathway (46). The therapeutic effect of SAL on a variety of tumors has been confirmed, including colorectal cancer (12), gastric cancer (47), bladder cancer (14), ovarian cancer (15), breast cancer (48) and Wilms' tumor (17); however, its role in promoting T-ALL apoptosis and autophagy and its molecular mechanism are not clear. In the present study, the protein expression levels of cleaved-PARP, Bax and LC3 were increased, while BCL-2 protein expression level was decreased in the CEM-C1 and CEM-C7 cells following treatment with SAL. This indicated that SAL could be a potential treatment for T-ALL. It was also found that DEX could induce apoptosis and autophagy in the CEM-C1 cells. In addition, when $1.5 \mathrm{mg} / \mathrm{ml} \mathrm{SAL} \mathrm{(cell} \mathrm{inhibition} \mathrm{rate,}<4 \%$ ) was combined with DEX, the induction of apoptosis and autophagy was significantly increased $(\mathrm{P}<0.01)$ compared with that in the DEX group.

Previous studies have shown that DEX resistance was associated with upregulation of the oncogene c-Myc mRNA expression $(10,49)$. In a separate study, Bhadri et al (50) demonstrated that in vivo DEX treatment in a DEX-sensitive ALL xenograft caused significant repression of c-Myc mRNA expression. In the present study, it was found that the CEM-C1 cells exhibited a higher protein expression level of c-Myc compared with that in the CEM-C7 cells. Long et al (51) demonstrated that imatinib-resistant K562/G cells exhibited high protein expression level of c-Myc compared with that in the parental K562 cells, and the c-Myc inhibitor 10058-F4 was found to reverse resistance caused by high expression level of c-Myc. It has also been shown that c-Myc inhibitors can produce synergistic anti-cancer effects with vincristine and sensitize pre-B-ALL cells to the anti-tumor effects of this chemotherapeutic drug by inducing apoptosis and autophagy (52). Sayyadi et al (53) demonstrated that c-Myc inhibition, using 10058-F4, increased the sensitivity of acute promyelocytic leukemia cells to arsenic trioxide. The results from the present study demonstrated that SAL could reduce c-Myc protein and mRNA expression levels. Notably, the combination treatment of SAL with DEX resulted in a more significant inhibition of c-Myc expression compared with that in the DEX group. Therefore, future studies should combine c-Myc inhibitors with SAL to verify their effects on apoptosis and autophagy, and the sensitivity to T-ALL cells to DEX.

In summary, the present study demonstrated the reversal effect of SAL on DEX resistance in the CEM-C1 cell line and confirmed that SAL exhibited an optimal effect on inhibiting proliferation, and induced apoptosis and autophagy in both the CEM-C1 and CEM-C7 cells. The CEM-C1 cells were more sensitive to SAL. SAL may overcome the resistance of the CEM-C1 cells to DEX by downregulating c-Myc protein and mRNA expression level. DEX resistance is a challenging problem for T-ALL chemotherapy. This provides a new treatment strategy for overcoming drug resistance and new evidence for clarifying the molecular mechanism of T-ALL-associated DEX resistance. The data further suggested that c-Myc may be a target for treating T-ALL resistance to DEX.

\section{Acknowledgements}

Not applicable.

\section{Funding}

This study was supported by the Basic Research Project of Sichuan Province (grant no. 2019YJ0690), Luzhou Science and Technology Plan Project (grant nos. 2019-RCW-96 and 2019-RCM-98) and the Major Science and Technology Projects in Sichuan Province (grant no. 2019YFS0531).

\section{Availability of data and materials}

The datasets used and/or analyzed during the present study are available from the corresponding author on reasonable request.

\section{Authors' contributions}

WJL designed and conceived the current study. YNN and YZ performed the experiments, analyzed the data and drafted and wrote the manuscript. FFZ, SLL, DWR and XQ contributed to analysis and interpretation of data, drafted the manuscript and revised it critically for important intellectual content. YNN, YZ and WJL confirm the authenticity of all the raw data. All authors have read and approved the final manuscript.

\section{Ethics approval and consent to participate}

Not applicable. 


\section{Patient consent for publication}

Not applicable.

\section{Competing interests}

The authors declare that they have no competing interests.

\section{References}

1. Zhou R, Mo W, Wang S, Zhou W, Chen X and Pan S: miR-141-3p and TRAF5 network contributes to the progression of T-cell acute lymphoblastic leukemia. Cell Transplant 28 (Suppl-1): S59-S65, 2019.

2. Qin X, Zhang MY and Liu WJ: Application of minimal residual disease monitoring in pediatric patients with acute lymphoblastic leukemia. Eur Rev Med Pharmacol Sci 22: 6885-6895, 2018.

3. Dufinck K, Goossens S, Peirs S, Wallaert A, Van Loocke W Matthijssens F, Pieters T, Milani G, Lammens T, Rondou P, et al: Novel biological insights in T-cell acute lymphoblastic leukemia Exp Hematol 43: 625-639, 2015.

4. Bongiovanni D, Tosello V, Saccomani V, Dalla-Santa S, Amadori A, Zanovello P and Piovan E: Crosstalk between Hedgehog pathway and the glucocorticoid receptor pathway as a basis for combination therapy in T-cell acutelymphoblastic leukemia. Oncogene 39: 6544-6555, 2020.

5. Lin KT and Wang LH: New dimension of glucocorticoids in cancer treatment. Steroids 111: 84-88, 2016.

6. Scheijen B: Molecular mechanisms contributing to glucocorticoid resistance in lymphoid malignancies. Cancer Drug Resist 2 647-664, 2019.

7. Verbeke D, Demeyer S, Prieto C, de-Bock CE, De-Bie J, Gielen O, Jacobs K, Mentens N, Verhoeven BM, Uyttebroeck A, et al: The XPO1 inhibitor KPT-8602 synergizes with dexamethasone in acutelymphoblastic leukemia. Clin Cancer Res 26: 5747-5758, 2020

8. Jing D, Bhadri VA, Beck D, Thoms JA, Yakob NA, Wong JW, Knezevic K, Pimanda JE and Lock RB: Opposing regulation of BIM and BCL2 controls glucocorticoid-induced apoptosis of pediatric acute lymphoblastic leukemia cells. Blood 125 273-283, 2015

9. Roderick JE, Gallagher KM, Murphy LC, O'Connor KW, Tang K, Zhang B, Brehm M, Greiner DL, Yu J, Zhu LJ, et al Prostaglandin E2 stimulates cAMP signaling and re-sensitizes human leukemia cells to glucocorticoid-induced cell death. Blood: Aug 5, 2020 (Epub ahead of print).

10. Toscan CE, Jing D, Mayoh C and Lock RB: Reversal of glucocorticoid resistance in paediatric acute lymphoblastic leukaemia is dependent on restoring BIM expression. Br J Cancer 122: 1769-1781, 2020.

11. Meyer LK, Huang BJ, Delgado-Martin C, Roy RP, Hechmer A, Wandler AM, Vincent TL, Fortina P, Olshen AB, Wood BL, et al: Glucocorticoids paradoxically facilitate steroid resistance in T-cell acute lymphoblastic leukemias and thymocytes. J Clin Invest 130: 863-876, 2020.

12. Shi X, Zhao W, Yang Y, Wu S and Lv B: Salidroside could enhance the cytotoxic effect of L-OHP on colorectal cancer cells. Mol Med Rep 17: 51-58, 2018.

13. Qi Z, Tang T, Sheng L, Ma Y, Liu Y, Yan L, Qi S, Ling L and Zhang Y: Salidroside inhibits the proliferation and migration of gastric cancer cells via suppression of Src-associated signaling pathway activation and heat shock protein 70 expression. Mol Med Rep 18: 147-156, 2018.

14. Li T, Xu K and Liu Y: Anticancer effect of salidroside reduces viability through autophagy/PI3K/Akt and MMP-9 signaling pathways in human bladder cancer cells. Oncol Lett 16: 3162-3168, 2018

15. Yu G, Li N, Zhao Y, Wang W and Feng XL: Salidroside induces apoptosis in human ovarian cancer SKOV3 and A2780 cells through the 53 signaling pathway. Oncol Lett 15: 6513-6518, 2018

16. Zhao G, Shi A, Fan Z and Du Y: Salidroside inhibits the growth of human breast cancer in vitro and in vivo. Oncol Rep 33: 2553-2560, 2015.

17. Li H,Huang D and Hang S: Salidroside inhibits the growth, migration and invasion of Wilms' tumor cells through down-regulation of miR-891b. Life Sci 222: 60-68, 2019.
18. Qin Y, Liu HJ, Li M, Zhai DH, Tang YH, Yang L, Qiao KL, Yang JH, Zhong WL, Zhang Q, et al: Salidroside improves the hypoxic tumor microenvironment and reverses the drug resistance of platinum drugs via HIF-1 $\alpha$ signaling pathway. EBioMedicine 38: 25-36, 2018.

19. Pelengaris S, Khan M and Evan G: c-MYC: More than just a matter of life and death. Nat Rev Cancer 2: 764-776, 2002.

20. Fauriat C and Olive D: AML drug resistance: c-Myc comes into play. Blood 123: 3528-3530, 2014.

21. Ji W, Zhang W, Wang X, Shi Y, Yang F, Xie H, Zhou W, Wang S and Guan X: c-myc regulates the sensitivity of breast cancer cells to palbociclib via c-myc/miR-29b-3p/CDK6 axis. Cell Death Dis 11: 760, 2020.

22. Pyko IV, Nakada M, Sabit H, Teng L, Furuyama N, Hayashi Y, Kawakami K, Minamoto T, Fedulau AS and Hamada J: Glycogen synthase kinase $3 \beta$ inhibition sensitizes human glioblastoma cells to temozolomide by affecting O6-methylguanine DNA methyltransferase promoter methylation via c-Myc signaling. Carcinogenesis 34: 2206-2217, 2013.

23. Tan Y, Sementino E, Chernoff J and Testa JR: Targeting MYC sensitizes malignant mesothelioma cells to PAK blockage-induced cytotoxicity. Am J Cancer Res 7: 1724-1737, 2017.

24. Ge JC, Yu WD, Li JH, Ma HB, Wang PY, Zhou YH, Wang Y, Zhang J and Shi GW: USP16 regulates castration-resistant prostate cancer cell proliferation by deubiquitinating and stablizing c-Myc. J Exp Clin Cancer Res 40: 59, 2021.

25. Yi XL, Lou LP, Wang J, Xiong J and Zhou S: Honokiol antagonizes doxorubicin resistance in human breast cancer via miR-188-5p/FBXW7/c-Myc pathway. Cancer Chemother Pharmacol: Feb 5, 2021 (Epub ahead of print).

26. Monga J, Subramani D, Bharathan A and Ghosh J: Pharmacological and genetic targeting of 5-lipoxygenase interrupts c-Myc oncogenic signaling and kills enzalutamide-resistant prostate cancer cells via apoptosis. Sci Rep 10: 6649, 2020.

27. Sheng Q, Zhang Y, Wang Z, Ding J, Song Y and Zhao W: Cisplatin-mediated down-regulation of miR-145 contributes to up-regulation of PD-L1 via the c-Myc transcription factor in cisplatin-resistant ovarian carcinoma cells. Clin Exp Immunol 200: 45-52, 2020.

28. Livak KJ and Schmittgen TD: Analysis of relative gene expression data using real-time quantitative PCR and the 2(-Delta Delta $\mathrm{C}(\mathrm{T})$ ) method. Methods 25: 402-408, 2001

29. Hirasawa $\mathbf{M}$ and Kurita-Ochiai T: Porphyromonasgingivalis induces apoptosis and autophagy via ER stress in human umbilical vein endothelial cells. Mediators Inflamm 2018: 1967506 , 2018.

30. Paglin S, Hollister T, Delohery T, Hackett N, McMahill M, Sphicas E, Domingo D and Yahalom J: A novel response of cancer cells to radiation involves autophagy and formation of acidic vesicles. Cancer Res 61: 439-444, 2001.

31. Zhang Y, Zhang Y, Jin XF, Zhou XH, Dong XH, Yu WT and Gao WJ: The role of astragaloside IV against cerebral ischemia/reperfusion injury: Suppression of apoptosis via promotion of P62-LC3-autophagy. Molecules 24: 1838, 2019.

32. Kim D, Hwang HY, Kim JY, Lee JY, Yoo JS, Marko-Varga G and Kwon HJ: FK506, an immunosuppressive drug, induces autophagy by binding to the V-ATPase catalytic subunit a in neuronal cells. J Proteome Res 16: 55-64, 2017.

33. Jin X, Fang R, Fan P, Zeng L, Zhang B, Lu X and Liu T: PES1 promotes BET inhibitors resistance and cells proliferation through increasing c-Myc expression in pancreatic cancer. J Exp Clin Cancer Res 38: 463, 2019.

34. Robinson AM, Rathore R, Redlich NJ, Adkins DR, VanArsdale T, Van Tine BA and Michel LS: Cisplatin exposure causes c-Myc-dependent resistance to CDK4/6 inhibition in HPV-negative head and neck squamous cell carcinoma. Cell Death Dis 10: 867-879, 2019.

35. Lv M, Wang Y, Wu W, Yang S, Zhu H, Hu B, Chen Y, Shi C, Zhang Y, Mu Q and Ouyang G: C-Myc inhibitor 10058-F4 increases the efficacy of dexamethasone on acute lymphoblastic leukaemia cells. Mol Med Rep 18: 421-428, 2018.

36. Huang HP, Liu WJ, Guo QL and Bai YQ: Effect of silencing HOXA5 gene expression using RNA interference on cell cycle and apoptosis in Jurkat cells. Int J Mol Med 37: 669-678, 2016.

37. Capria S, Molica M, Mohamed S, Bianchi S, Moleti ML, Trisolini SM, Chiaretti S and Testi AM: A review of current induction strategies and emerging prognostic factors in the management of children and adolescents with acute lymphoblastic leukemia. Expert Rev Hematol 13: 755-769, 2020. 
38. Yu Y, Yu X, Ma J, Tong Y and Yao J: Effects of NVP-BEZ235 on the proliferation, migration, apoptosis and autophagy in HT-29 human colorectal adenocarcinoma cells. Int J Oncol 49: 285-293, 2016.

39. Vazanova A, Jurecekova J, Balharek T, Marcinek J, Stasko J, Dzian A, Plank L, Zubor P, Racay P and Hatok J: Differential mRNA expression of the main apoptotic proteins in normal and malignant cells and its relation to in vitro resistance. Cancer Cell Int 18: 33, 2018.

40. Klionsky DJ, Abdel-Aziz AK, Abdelfatah S, Abdellatif M, Abdoli A, Abel S, Abeliovich H, Abildgaard MH, Abudu YP, Acevedo-Arozena A, et al: Guidelines for the use and interpretation of assays for monitoring autophagy (4rd edition). Autophagy 17: 1-382, 2021.

41. Fu Y, Zhang Y, Gao M, Quan L, Gui R and Liu J: Alisertib induces apoptosis and autophagy through targeting the AKT/mTOR/AMPK/p38 pathway in leukemic cells. Mol Med Rep 14: 394-398, 2016.

42. Goldar S, Khaniani MS, Derakhshan SM and Baradaran B Molecular mechanismsof apoptosis and roles in cancer development and treatment. Asian Pac J Cancer Prev 16: 2129-2144, 2015

43. Thorburn A, Thamm DH and Gustafson DL: Autophagy and cancer therapy. Mol Pharmacol 85: 830-838, 2014.

44. Long SL, Ren DW, Zhong FF, Niu YN, Qin X, Mu D and Liu WJ Reversal of glucocorticoid resistance in acute lymphoblastic leukemia cells by miR-145. PeerJ 8: e9337, 2020.

45. Magani SKJ, Mupparthi SD, Gollapalli BP, Shukla D, Tiwari AK, Gorantala J, Yarla NS and Tantravahi S: Salidroside-can it be a multifunctional drug. Curr Drug Metab 21: 512-524, 2020.

46. Fan XJ, Wang Y, Wang L and Zhu M: Salidroside induces apoptosis and autophagy in human colorectal cancer cells through inhibition of PI3K/Akt/mTOR pathway. Oncol Rep 36: $3559-3567,2016$
47. Zhang ZD, YangW, Ma F, Ma Q, Zhang B, Zhang YL, Liu YQ, Liu HX and Hua YW: Enhancing the chemotherapy effect of Apatinib on gastric cancer by co-treating with salidroside to reprogram the tumor hypoxia micro-environment and induce cell apoptosis. Drug Deliv 27: 691-702, 2020

48. Yu X, Sun LL, Tan LJ, Wang M, Ren XL, Pi JX, Jiang MM and Li N: Preparation and characterization of PLGA-PEG-PLGA nanoparticles containing salidroside and tamoxifen for breast cancer therapy. AAPS PharmSciTech 21: 85, 2020.

49. Beesley AH, Firth MJ, Ford J, Weller RE, Freitas JR, Perera KU and Kees UR: Glucocorticoid resistance in T-lineage acute lymphoblastic leukaemia is associated with a proliferative metabolism. Br J Cancer 100: 1926-1936, 2009.

50. Bhadri VA, Cowley MJ, Kaplan W, Trahair TN and Lock RB: Evaluation of the NOD/SCID xenograft model for glucocorticoid-regulated gene expression in childhood B-cell precursor acute lymphoblastic leukemia. BMC Genomics 12: 565, 2011.

51. Long ZJ, Fang ZG, Pan XN, Fan RF and Lin DJ: Inhibition of c-Myc by $10058-\mathrm{F} 4$ overcomes imatinib resistance in chronic myeloid leukemia cells. Chin J Pathophysiol 30: 1590-1594, 2014.

52. Sheikh-Zeineddini N, Safaroghli-Azar A, Salari S and Bashash D: C-Myc inhibition sensitizes pre-B ALL cells to the anti-tumor effect of vincristine by altering apoptosis and autophagy: Proposing a probable mechanism of action for 10058-F4. Eur J Pharmacol 870: 172821, 2020.

53. Sayyadi M, Safaroghli-Azar A, Pourbagheri-Sigaroodi A, Abolghasemi H, Anoushirvani AA and Bashash D: c-Myc inhibition using 10058-F4 increased the sensitivity of acute promyelocytic leukemia cells to arsenic trioxide via blunting PI3K/NF-KB axis. Arch Med Res 51: 636-644, 2020.

This work is licensed under a Creative Commons Attribution-NonCommercial-NoDerivatives 4.0 International (CC BY-NC-ND 4.0) License. 